Обуховська О. В., кандидат ветеринарних наук

Національний науковий центр

«Інститут експериментальної і клінічної ветеринарної медицини»

\title{
ВИЗНАЧЕННЯ РІВНЯ ПРОТЕКТИВНОГО ЗАХИСТУ ІНАКТИВОВАНОЇ ВАКЦИНИ ПРОТИ РЕСПІРАТОРНОГО МІКОПЛАЗМОЗУ ПТИЦІ В ДОСЛІДІ НА КУРЧАТАХ
}

\section{Рецензент - кандидат ветеринарних наук К. В. Глєбова}

\begin{abstract}
Визначено протективні властивості експериментальної серії інактивованої вакцини проти респіраторного мікоплазмозу птиці в досліді на курчатах. В якості виробничого застосовували штам Mycoplasma gallisepticum $S_{6}$, інактивачію здійснювали шляхом додавання $1 \%$ формальдегіду. До стандартизованої інактивованої антигенної основи додавали ад 'ювант із розрахунку: $30 \%$ антигенної основи ( $3 \times 10^{7} \mathrm{KУO)} \mathrm{та} 70 \%$ ад юванту (Mantanide ISO-70). Доведено, щзо за умов дворазового внутрішньом'язевого щееплення вакцина забезпечує захист $100 \%$ птиці від клінічних проявів захворювання та забезпечує захист $95 \%$ птиці від зараження штамом-пробійником.
\end{abstract}

Ключьові слова: інактивована вакцина, респіраторний мікоплазмоз птиці.

Постановка проблеми. Застосування вакцин для профілактики респіраторного мікоплазмозу в продуктивних і племінних стадах птиці доводить економічну ефективність та епізоотичну доцільність імунізації $[1,4,12]$. Чимало вчених наголошують також на доцільності застосування виключно інактивованих емульсин-вакцин [2, 3, 7-9]. Вітчизняних розробок щодо таких препаратів на сьогодні немає. Тому робота в цьому напрямі є актуальною й необхідною.

Аналіз основних досліджень і публікацій, у яких започатковано розв'язання проблеми. Критично оцінюючи переваги й недоліки живих та інактивованих вакцин, D. Shapiro наголошує, що інактивовані вакцини безпечні, за умов їх застосування не спостерігають інтерференції, забезпечують тривалу та досить «однорідну» імунну відповідь [10].

За даними D. E. Page et all, застосування чотирьох експериментальних серій емульсин-вакцин на основі інактивованого бактерину забезпечувало високий рівень імунного захисту у 88-100 \% птиці за умов двократного підшкірного введення [6]. На високу ефективність застосування вакцин з інактивованого бактерину вказує Z. Zolli. Вiн довів, що одноразова імунізація птиці шляхом внутріш- ньосинусного введення сприяла формуванню у 80 \% птиці напруженого імунітету; при цьому доцільніше вакцинувати птицю у віці від 16 до 28 тижнів [13]. Karaca K. та Lam K. М. показали, що імунізація інактивованою емульсин-вакциною зі штаму $M$. gallisepticum $\mathrm{S}_{6}$ захищає 100 \% курчат від експериментального зараження вірулентним штамом мікоплазм [5]. Як встановили F. D. Talkington i S. H. Kleven, одно- та дворазова імунізація курчат інактивованою вакциною (M. gallisepticum) захищає $100 \%$ птиці від зараження вірулентним штамом. Однак, у разі введення інтратрахеально великої кількості КУО мікоплазм визначали наявність патогена на слизовій оболонці трахеї у вакцинованої птиці за умов відсутності клінічних та патологоанатомічних ознак респіраторного мікоплазмоз [11]. Протективні властивості, а саме забезпечення захисту від клінічних маніфестацій інфекції, - головна характеристика вакцинних препаратів проти респіраторного мікоплазмозу птиці. Тому в разі розробки вітчизняних вакцин цей показник повинен бути вивчений у першу чергу.

Мета дослідження. Метою досліджень було вивчення протективних властивостей експериментальної серії інактивованої вакцини проти респіраторного мікоплазмозу птиці за умов зараження вакцинованих особин вірулентним штамом Mycoplasma gallisepticum $S_{6}$.

Матеріали та методи. У процесі виготовлення вакцини в якості виробничого застосовували музейний штам Mycoplasma gallisepticum $S_{6}$. Бакмасу мікоплазм накопичували на рідкому поживному середовищі ННЦ на основі триптичного гідролізату серця ВРX із сироватковим альбуміном ВРX.

Антигенну основу вакцини виготовляли за такою методикою: 5-добову культуру мікоплазм знешкоджували шляхом додавання $1 \%$ формальдегіду (режим інактивації - 2 доби за температури $37,5^{\circ} \mathrm{C}$ ). Інактивовану бактерійну масу відмивали триразово стерильним ФБФР шляхом 
центрифугування за 5 тис. об./хв. протягом 20 хвилин. Супернатант утилізували, а клітинну масу стандартизували стерильним ФБФР до концентрації $1 \times 10^{8} \mathrm{KУO} / \mathrm{cm}^{3}$.

Контроль повноти інактивації мікоплазм здійснювали шляхом висіву в об'ємі $0,5 \mathrm{~cm}^{3}$ на рідке поживне середовище. Режим інкубації (5 діб за температури $\left.(37 \pm 0,5)^{\circ} \mathrm{C}\right)$. До стандартизованої інактивованої антигенної основи додавали ад’ювант із розрахунку: $30 \%$ антигенної основи

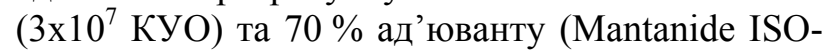
70). Виготовлену вакцину перевіряли на стерильність (за ДСТУ 4483) та нешкідливість (за ДСТУ 46.024). Протективні властивості вакцини перевіряли в досліді на курчатах. Було сформовано дві групи птиці (дослідна та контрольна) за принципом аналогів, по 20 гол. кожна. Птиця дослідної групи була щеплена дворазово вакциною в віці 30 та 60 діб у дозі $0,3 \mathrm{~cm}^{3}$ внутрішньом'язево. Птиця контрольної групи не була щеплена. У віці 110 діб птиця обох груп була інфікована 5-добовою культурою Mycoplasma gallisepticum $S_{6}$ інтраназально, внутрішньом'язево та інтраторакально (всього кожній голові було інокульовано $1 \times 10^{9}$ КУО мікоплазм). За птицею вели спостереження впродовж 30 діб. На 14-у, 21-у та 30-у добу відбирали назальні змиви для бакте-ріологічних досліджень. На 31-у добу птиця була забита, внутрішні органи (носових хоан, трахеї, легень, торакальних повітроносних міхурів та довгастого мозку) були піддані бактеріологічному дослідженню.

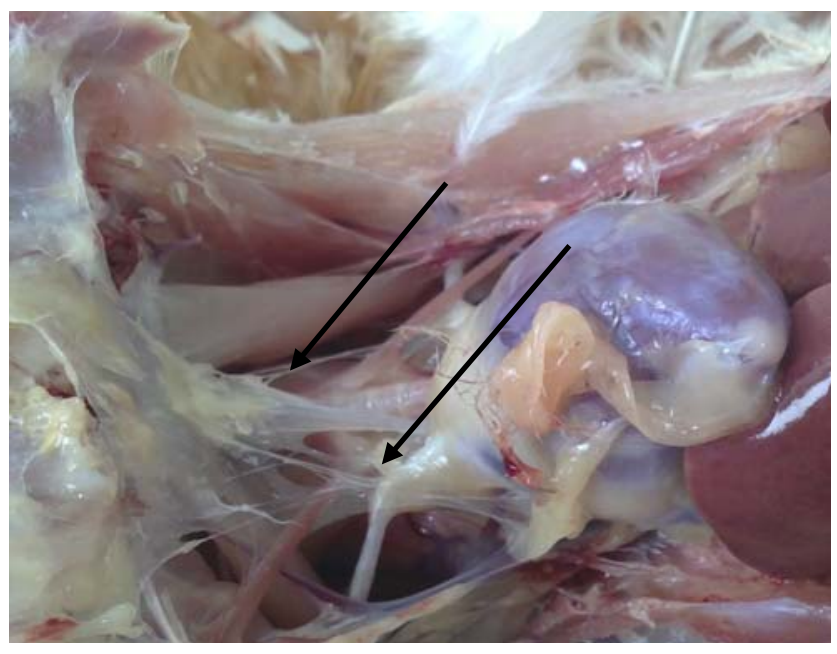

Рис. 1. Аеросаккуліт у птиці контрольноӥ групи
Результати дослідження. Спостереження за птицею дослідної групи показали, що після першого та другого введень вакцини місцевих реакцій і загальних фізіологічних змін не було зафіксовано. Впродовж усього періоду спостереження у птиці ніяких клінічних ознак не виявляли.

У назальних змивах від курей дослідної групи на 14-у та 21-у добу після інфікування мікоплазми ізольовані не були. На 30-у добу культуру M. gallisepticum $\mathrm{S}_{6}$ ізолювали від однієї особини 3 дослідної групи (зі слизової трахеї). У ході проведення розтину у птиці дослідної групи не виявили патологоанатомічних змін, характерних для респіраторного мікоплазмозу.

На 15-ту добу після інфікування у курей контрольної групи виявили загальне пригнічення, слабкість, відмову від їжі. На 16-21-у добу в усієї птиці даної групи були наявні такі клінічні симптоми: трахеальні хрипи, задишка, кашель, у окремих особин - набряки навколоочних синусів.

За патологоанатомічного розтину у птиці контрольної групи виявляли серозний аеросаккуліт (рис. 1) та перикардит, вогнищеве запалення легенів (рис. 2).

У назальних змивах від курей цієї групи культуру M. gallisepticum $\mathrm{S}_{6}$ ізолювали, починаючи 3 14-ї доби. Зі слизової трахеї, проб легенів і повітроносних міхурів у всіх особин та 3 довгастого мозку 12-ти особин контрольної групи була виділена культура M. gallisepticum $\mathrm{S}_{6}$.

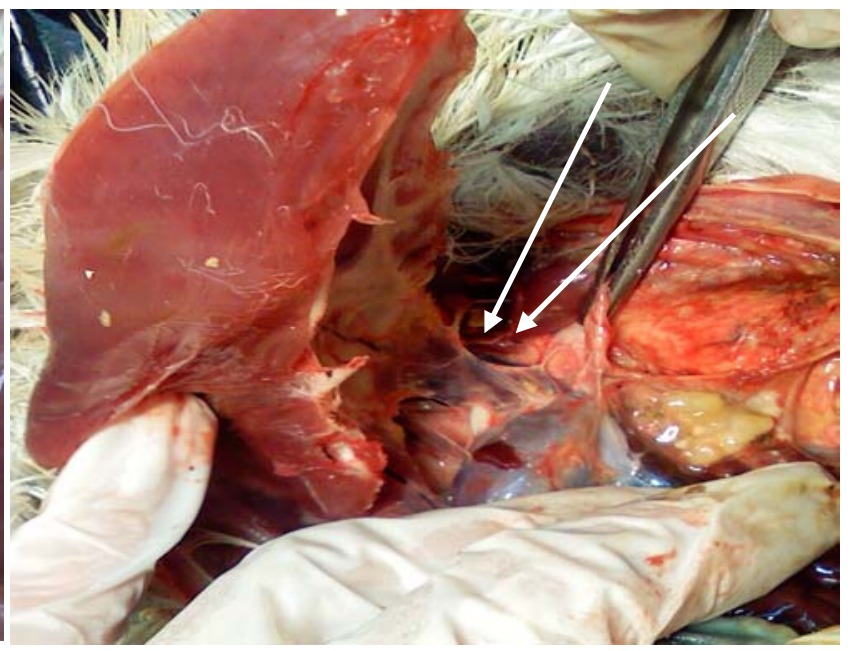

Рис. 2. Вогнищеве запалення легенів у птиці контрольної групи 


\section{Висновки:}

1. Визначено, що інактивована вакцина проти респіраторного мікоплазмозу птиці $є$ нешкідливою та не спричиняє місцевих і загальних реакцій на введення.

2. Виявлено, що за умов дворазового внутрішньом'язевого щеплення інактивована вакцина

\section{БІБЛІОГРАФІЯ}

1. Anon A. Sintesi relazione Volten [Text] / A. Anon// Unavicoltura. - 1987. - Vol. 23, № 9. P. 18-20.

2. Barbur E. K. Infection and immunity in broiler chicken breeders vaccinated with a temperaturesensitive mutant of Mycoplasma gallisepticum and impact on performance of offspring [Text] / E. K. Barbur, S. K. Hamadeh, A. Eid // Poultry Sc. 2000. - Vol. 79, № 12. - P. 1730-1735.

3. Effects of an $\mathrm{S}_{6}$ strain of Mycoplasma gallisepticum challenge before beginning of lay on various egg characteristics in commercial layers [Text] / T. A. Parker [et al.] // Avian Dis. - 2002. - Vol. 46, № 3. -P. 593-597.

4. Jutta B. U. Mycoplasma eradication by egg injection [Text] / B. U. Jutta // Poultry. - 1985. Vol. 24, № 13. - P. 28-30.

5. Karaca K. An inactivated temperature-semsitive Mycoplasma gallisepticum mutant for protection against airsacculitis [Text] / K. Karaca, K. M. Lam // Avian Phatol. - 1987. - Vol. 16, № 3. - P. 513519.

6. Page D. E. Laboratory and field evaluation of an inactivated Mycoplasma synoviae (MS) bacterin [Text] / D. E. Page, D. G. Hildebrand, J. B. Korshus // Proceeding of $33^{\text {rd }}$ Western poultry diseases conference, 1984. - P. 53-54.

7. Preliminary study of the adjuvant emulsion проти респіраторного мікоплазмозу птиці забезпечує стовідсотковий захист птиці від клінічних проявів захворювання.

3. Показано, що застосування інактивованої вакцини, створеної за розробленою нами технологією, захищає 95 \% птиці від зараження штамом M. gallisepticum $\mathrm{S}_{6}$.

Montanide ISA-50 and Mycoplasma gallisepticum antigen [Text] / L. Sanchez [et al.] // Rev. Salud anim. - 2004. - Vol. 26, № 3. - P. 213-215.

8. Prove di vaccinazione in campo contro le infezioni aviarie da Mycoplasma gallisepticum [Text] / D. Gallazzi [et al.] // Clin. veter. - 1985. - T. 108, № 2. - P. 115-121.

9. Rozina A. Evaluation of efficacy of formaldehyde treated Mycoplasma gallisepticum vaccine in broiler chicken [Text] / A. Rozina, M. A. Khan // Pakistan J. of Scintific and Research. - 2002. - Vol. 45, № 4. P. 284-290.

10. Shapiro $D$. Inactivated vaccines theory and practice [Text] / D. Shapiro // Poultry. - 1985. - Vol. 1, № 5. - P. 36-39.

11. Talkington F. D. Evaluation of protection against colonization of the chicken trachea following administration of mycoplasma gallisepticum bacterin [Text] / F. D. Talkinington, S. H. Kleven // Avian Dis. - 1985. - Vol. 29, № 4. - P. 998-1003.

12. Uribe Serrano A. J. Use of vaccines to control Mycoplasma gallisepticum [Text] / A. J. Uribe Serrano // International Hatchery Practice. - 2001. Vol. 16, № 2. - P. 15-17.

13. Zolli Z. Mycolasma gallisepticum field evaluation on the use and efficacy of a MG bacterin [Text] / Z. Zolli // Proceeding of $33^{\text {rd }}$ Western poultry disease conference, 1984. - P. 49-51. 